\title{
A Comparative Study of the Effectiveness between Jigsaw technique and Conventional technique on Reading Comprehension for Grade VII Students of State Junior High School in Purwokerto
}

\author{
${ }^{1 s t}$ Falah Rufaida \\ Applied Linguitic, Graduate School \\ Yogyakarta State University \\ Yogyakarta, Indonesia \\ Falah.rufaida2016@student.uny.ac.id
}

\author{
${ }^{2 n d}$ Haryadi \\ Applied Linguitic, Graduate School \\ Yogyakarta State University \\ Yogyakarta, Indonesia \\ Prof_haryadi@yahoo.co.id
}

\begin{abstract}
The study aims to compare the effectiveness of the Jigsaw technique and Conventional technique in improving the students' reading comprehension ability on the descriptive text material of year VII. This research was quasi experiment conducted at State Junior High School 2 Purwokerto in the second semester of the academic year of 2017/2018. The Jigsaw and Conventional techniques were the independent variables, while students' reading comprehension ability was the dependent variable. The Jigsaw and Conventional classes consisted of 34 , and 33 students respectively. The data collection used a test which had been tested theoretically and empirically by related experts. After the data were collected, the hypothesis testing used the t-test. The result of the hypothesis testing shows that the Jigsaw and Conventional techniques can improve students' reading comprehension ability. The Jigsaw technique proves to be more effective technique than Conventional technique. This can be seen from: (1) the post-test score, (2)the result of the t-test, which shows that the Jigsaw and Conventional classes show differences, (3) the Jigsaw class gets the higher average post-test score than Conventional class. Therefore, it can be concluded that the Jigsaw technique can be a good technique to improve students' reading comprehension ability in descriptive texts.
\end{abstract}

Keywords - conventional technique, jigsaw technique, reading comprehension

\section{INTRODUCTION}

Entering the globalization era, foreign language mastery is needed for everybody. The foreign language skills needed to facilitate communication one to another. It can be seen by mastery on the lingua franca e.g. English. Several major newspapers and magazines finds in the subject of the English language an apt symbol for the themes of globalization, diversification, progress and identity addressed in their special editions. Television programs and series, too, addressed the issue, and achieved worldwide audiences [1]. It can be strengthen the statement that English is the language that is used for connecting peoples having different tongues [2]. So that it is important for being English proficiency.

Mastery in English is not the easy way. People have to master on; speaking skill, writing skill, listening skill, and reading skill. Skill that is important and should be master in especially for students is reading skill; it makes them easy to read material that given in English [2].

Reading is the process of constructing meaning from written texts [3]. These important skills must be owned by individuals, especially for students, but it has not got a special place in students. Quoting from Jurnas.com, it explained the results of a survey conducted by the Program for International Students Assessment (PISA) in 2015. It stated that out of 72 participants, Indonesia got 63rd position [4]. Although it was stated that Indonesia had increased compared to last year, this position was still low. As is known that PISA is a program evaluating students especially in the field of science, mathematics, and one of them is reading. The results of this survey indicate a linguistic problem that must be resolved, namely reading.

Besides that, problems also arise from the results of the English national examination (UN) on junior high school students. Based on Republika.com article, there was a decline score on students' UN score, especially in English and Indonesian. National Examination is a written test form, and tests more reading skills than other language skills. So, this problem must be resolved immediately.

Our minister education had changed the curriculum. They replaced Kurikulum Tingkat Satuan Pendidikan (KTSP) into the 2013 Curriculum which invites students to think scientifically. The occurrence of the case, the technique applied to this curriculum has not shown any academic changes in students' abilities, 
especially the ability to read English students. So, this study tried to use the other technique on the learning process, it is Jigsaw technique.

Several studies had investigated the effectiveness of Jigsaw techniques on the teaching and learning process, one of which was a study conducted by Madu (2018) that applied Jigsaw to Math lesson. He could prove that Jigsaw was effective in increasing students' math achievement [6]. The second was Basyah's study (2017). He proved that Jigsaw technique in teaching-learning economics lesson can be a model for improving students' achievement [7]. Previous research reinforces Jigsaw is appropriate to solve student problems. This study, researchers tried to investigate if the jigsaw technique was applied to improve students' reading comprehension ability. The formulation of the problem is as follows:

1. Are there differences in post-test scores between conventional technique and Jigsaw technique in improving students' reading comprehension ability?

2. Between conventional technique and Jigsaw technique which technique is more effective in improving students' reading comprehension ability?

\section{READING COMPREHENSION}

Reading is to understand the meaning of printed words such as written symbols [2]. This activity is not only done in the context of interpreting symbolic writing, but the main purpose is to find out the message delivered. In other words, reading activity without understanding the message in the text is useless [8]. To comprehend the text is the important thing. It can be done by having a good reading comprehension ability.

The main activity in reading comprehension is combining knowledge with cognitive and metacognitive processes [9]. Readers try to remember the knowledge memory. This knowledge memory is combined with the information contained in the text. Thus, an understanding is formed.

There are two ways in reading; orally and silently. Both have different goals. Reading orally is intended to find out how the pronunciation ability speaks words. While silently, this is usually intended to understand the text [10]. This difference shows that silent reading is a reading technique that is often done to understand reading text.

On the other hand, in developing reading comprehension skills, there are two kinds of activities that can be done to develop it; extensive reading and intensive reading. Extensive reading in general the aim is to get a general understanding of what is read. In this activity, in addition to the reader getting an understanding of the text, the reader know how to develop good reading habits, and increase vocabulary and structure knowledge. In conclusion, this activity focuses on encouraging the desire to read. While intensive reading, this is done slowly. The main purpose is to understand the text more deeply than to read extensively [11].

\section{JIGSAW TECHNIQUE}

There have been kinds of Jigsaw technique, such as developed by Kagan, Slavin, Lawrence Hall of Science, and Coelho \& Winn-Bell Olsen [13]. This research used the origin Jigsaw. It was developed by Elliot Aronson and his associates. It is the first Jigsaw technique developed.

That makes this technique different than others technique on Cooperative learning that the Jigsaw technique consists of a regular instructional cycle of activities that include reading, grouping, regrouping, expert group discussion, team reporting, testing, and finally team recognition[12]. There is a team recognition that makes students had to cooperate to be successful. Working together, the students came to like each other and ethnic relations improved [13]. It makes every member have a responsibility being the success group.

Aronson (2000) explained there are ten stages on the implementing of Jigsaw [7]. In short in this learning process teachers make group consist of 5-6 students (it have to be in heterogeneous group). Give them the assignment and choose one of the members being a leader. Students who have the same assignment gather in a group to solve it. After it solve then back to original group and present it. At the last learning process they get quiz. Member quizzes score will be collected, group which have the highest number of score get reward.

\section{CONVENTIONAL TECHNIQUE}

In this study, conventional techniques use techniques based on the 2013 curriculum. Since academic year 2013/2014, Indonesian education has implemented the 2013 curriculum. This curriculum focus on the scientific approach (observing, asking, collecting information, associating, and communicating)[14]. The learning process is student-centered, authentic, contextual, and meaningful to students' daily lives. Students are invited to think like scientists in order to solve existing problems.

The learning process combines initiative and selfactivity, group collaboration, and professional guidance from the teacher [14]. This process is the reference in the use of conventional technique in this study. So, conventional technique is group discussion techniques to solve problems that have been presented.

\section{METHODS}

This research was a quasi-experimental research. It compared two difference techniques that applied on students' reading comprehension. They were Jigsaw technique and Conventional technique.

It was held in SMP N 2 Purwokerto. The population was the students of SMP N 2 Purwokerto. 
The samples were taken from VII C as Jigsaw class and VII E as Conventional class, each class consists of 34 and 33 students. It was selected, because they consist of heterogeneous students. Besides that, it was held on the second semester academic year 2017/2018.

For the variable, there were three variable used. They were Jigsaw technique and Conventional technique (teaching technique) as independent variable and students' reading comprehension ability as dependent variable.

For data collection, it was done by tests conducted before (pre-test) and after (post-test) teaching and learning process. The use of a pre-test was to hold matching score (pemadanan data). It was done because the pre-test data was in various score, so data matching was needed to match the pre-test score, while the posttest was used for hypothesis test. This post-test was from students who had the same score on the matching pre-test score. The instrument of collecting data was multiple choice tests. This instrument had been valid instrument, cause it had got validity and reliability instrument by the expert and empirically.

After data had collected, then data was tested by hypothesis test. This hypothesis test was done by $\mathrm{t}$ test. Before come in hypothesis test, it has to pass from the assumption test. It was done by normality test and Homogeneity test. They have done by KolmogorovSmirnov Test and levene's test that used SPSS 24.

\section{FINDING}

This study aims to compare the effectiveness of Jigsaw techniques and conventional techniques in improving students' reading comprehension ability. It can be seen from the pre-test and post-test scores that have been analyzed. The results of the pre-test and post-test are presented in the following table:

\begin{tabular}{|c|c|c|c|c|c|}
\hline TABLE1. & \multicolumn{2}{|c|}{$\begin{array}{c}\text { PRE-TEST } \\
\text { TECHNIQUE\& } \\
\text { TECHNIQUE }\end{array}$} & $\mathrm{SCO}$ & NVE & $\begin{array}{l}\text { IGSAW } \\
\text { IONAL }\end{array}$ \\
\hline Variable & $\mathrm{N}$ & $\begin{array}{l}\text { Mean } \\
\text { score }\end{array}$ & $\begin{array}{l}\text { Min. } \\
\text { score }\end{array}$ & $\begin{array}{l}\text { Max. } \\
\text { Score }\end{array}$ & $\begin{array}{c}\text { Std. } \\
\text { Deviati } \\
\text { on }\end{array}$ \\
\hline $\begin{array}{c}\text { Jigsaw } \\
\text { Technique }\end{array}$ & 34 & 70.2941 & 30.00 & 96.70 & $\begin{array}{c}19.058 \\
81 \\
\end{array}$ \\
\hline $\begin{array}{l}\text { Conventio } \\
\text { nal } \\
\text { Technique }\end{array}$ & 33 & 70.4061 & 30.00 & 96.70 & $\begin{array}{c}18.373 \\
37\end{array}$ \\
\hline
\end{tabular}

The results of the pre-test on Table 1., shows that the pre-test got by the Jigsaw class and Conventional class, are not significantly different, 70.2941 and 70.4062. This is also shown from the Std. Deviation score, Jigsaw technique got 19.05881 and Conventional techniques got 18.37337. While the maximum and minimum score are same, they are 96.70 and 30.00 .
TABLE 2. MATCHING DATA

\begin{tabular}{|c|c|c|c|c|}
\hline $\mathrm{N}$ & $\begin{array}{c}\text { Mean } \\
\text { score }\end{array}$ & $\begin{array}{c}\text { Min. } \\
\text { score }\end{array}$ & $\begin{array}{c}\text { Max. } \\
\text { score }\end{array}$ & $\begin{array}{c}\text { Std. } \\
\text { deviati } \\
\text { on }\end{array}$ \\
\hline 48 & 70.4167 & 30 & 96.70 & $\begin{array}{c}18.945 \\
06\end{array}$ \\
\hline
\end{tabular}

Based on the Table 2., there were 48 sample that had same pre-test score, it mean 24 students on each class. They got mean score 70.4167 from students. This is also shown from the Std. Deviation score, it was 18.94506. While the maximum and minimum score are 96.70 and 30.00 .

TABLE3. POST-TEST: JIGSAW TECHNIQUE \& CONVENTIONAL TECHNIQUE

\begin{tabular}{|l|l|l|l|l|l|}
\hline Variable & $\mathrm{N}$ & $\begin{array}{l}\text { Mean } \\
\text { score }\end{array}$ & $\begin{array}{l}\text { Min. } \\
\text { score }\end{array}$ & $\begin{array}{l}\text { Max. } \\
\text { score }\end{array}$ & $\begin{array}{l}\text { Std. } \\
\text { deviati } \\
\text { on }\end{array}$ \\
\hline $\begin{array}{l}\text { Jigsaw } \\
\text { Technique }\end{array}$ & 24 & $\begin{array}{l}80.004 \\
2\end{array}$ & 60.00 & 96.70 & $\begin{array}{l}10.773 \\
05\end{array}$ \\
\hline $\begin{array}{l}\text { Conventio } \\
\text { nal } \\
\text { Technique }\end{array}$ & 24 & $\begin{array}{l}70.554 \\
2\end{array}$ & 33.30 & 93.30 & $\begin{array}{l}16.110 \\
41\end{array}$ \\
\hline
\end{tabular}

The post-test results on table 2., shows that Jigsaw technique got 80.004 for the mean score and 10.773 for std. Deviation. Conventional techniques get 70.5542 for the mean score and 16.11041 for std. Deviation. There are differences on minimum score and maximum score. Jigsaw technique got 60.00 and 96.70. Conventional group got 33.30 and 93.30 .

TABLE 4. THE ASSUMPTION TEST (Post-test)

\begin{tabular}{|c|c|c|c|}
\hline \multicolumn{2}{|c|}{ Assumption test } & Sig. & \multirow{3}{*}{$\begin{array}{l}\text { Result } \\
\text { Data } \\
\text { distribution } \\
\text { is normal }\end{array}$} \\
\hline \multirow{2}{*}{$\begin{array}{l}\text { Normality } \\
\text { test } \\
\text { (Kolmogrov- } \\
\text { Smirnov } \\
\text { Test }\end{array}$} & \begin{tabular}{|l} 
Jigsaw \\
technique
\end{tabular} & 0.105 & \\
\hline & $\begin{array}{l}\text { Conventional } \\
\text { technique }\end{array}$ & 0.183 & \\
\hline \multicolumn{2}{|c|}{$\begin{array}{l}\text { Homogenity test (Levenes' } \\
\text { Test) }\end{array}$} & 0.97 & $\begin{array}{l}\text { Data } \\
\text { distribution } \\
\text { is homogent }\end{array}$ \\
\hline
\end{tabular}

Assumption test results show that the normality test gets 0.105 for Jigsaw technique and 0.183 for Conventional technique. They are more than 0.05 . It means the data is normally distributed. While the homogeneity test gets 0.97 for a significant score. This score is higher than 0.05 (0.97> 0.05). It means the data is homogeneous. Data has fulfilled the requirements on assumption tests, so it can continue on hypothesis testing.

TABLE 5. T-TEST RESULT

\begin{tabular}{|l|l|l|}
\hline Mean different & F & Sig. \\
\hline 9.45000 & 2.875 & 0.021 \\
\hline
\end{tabular}


The results of the t-test on table 3 show that there is a difference in the mean score on Post-test between Jigsaw technique and Conventional technique, it is 9.45000. Besides that the difference is also shown in the significance of the score, this gets 0.021 . It is less than $0.05(0.021<0.05)$. It means that there is a difference Post-test score between the control class and the experimental class.

\section{DISCUSSION}

Jigsaw is one of the technique learning of Cooperative learning. It was known with its expert group and original group [13]. It was believed this technique can increase students' enthusiasm to get good academic [15]. Studies had proved it could improve students' achievement, e.g. Madu's study (2018). He could prove Jigsaw can improve students' math achievement. Besides that, it was Basya's study (2017). He also could prove Jigsaw effective to improve students' achievement on Economic lesson. My study result in comparing Jigsaw technique and Conventional technique, Jigsaw is more effective than Conventional technique. It can be seen on the post-test mean score. On pre-test mean score, they got 70.4167. For post-test, Jigsaw technique got 80.0042 and Conventional technique got 70.5542 Thus, Jigsaw is not only effective improving students' Math and Economic lesson achievement, but it also is effective in improving students' reading comprehension ability.

Although this research can prove that Jigsaw technique is more effective than conventional techniques in improving students' reading ability, this study has limitations. One of them is the focus of research. Although Jigsaw has advantages that can be used for teaching and learning process, the focus of this study was to improve students' reading comprehension skills. Thus, it is expected that later there will be research discussing Jigsaw techniques in other education materials.

\section{Acknowledgement}

I would like to thank my supervisor, Prof. Haryadi, M. $\mathrm{Pd}$. had guided me during the research process. I said to the mrs. Titik Ernawati as the English teacher of SMP N 2 Purwokerto. and to all who can't mention, thanks for helping me during reserach process

\section{References}

[1.] D. Crystal, "English as a global language: Cambridge University Press, pp. 1-28, 1989.

[2.] M.F. Patel and P.M. Jain, "English Language," 2008.
[3.] R.C. Anderson,E. H. Hiebert, J. A. Scott, and I. A. G. Wilkinson, Becoming a nation of readers. 1985:7-18.

[4.] http://www.jurnas.com/artikel/31315/PergerakanPisa-Indonesia-Cenderung-Meningkat/

https://republika.co.id/berita/pendidikan/eduact ion/17/06/15/orkzom382-nilai-un-smp-bahasaindonesia-dan-bahasa-inggris-anjlok

[6.] T. M. Yemi, N. B. H. Azid, M. R. B. M. Ali, "Effect of jigsaw strategy of cooperative learning on mathematics achievement among secondary School Students." Europian Journal of Education Studies, Vol. 4, Issue 2 2018:5161.

doi:10.5281/zenodo. 1167888

[7.] N. A. Basyah, A. Muslem, and B. Usman, "The Effectiveness of Using the Jigsaw Model to Improve Students' Economics TeachingLearning Achievement," 2018. The new educational review.

DOI: 10.15804/tner.2017.50.4.02 Abstract

[8.] S. Ampuni, "Proses Kognitif Dalam Pemahaman Bacaan," Buletin Psikologi, Tahun VI, No. 2 Desember 1998 :16-26. doi:10.22146/bpsi.7395

[9.] W. S. Hall, "Reading Comprehension," 2011;44(2):15-35.

doi:10.1007/978-94-007-1174-7

[10.] H. D. Brown, "Teaching by Principles. An Interact Approach to Language Pedagogy," Longman, 2000

[11.] J. C. Richard, and R. Schimidt, "Longman Dictionary of Language Teaching and Applied Linguistics,"

2010. doi:10.4324/9781315833835

[12.] S. S. Sabbah, "The Effect of Jigsaw Strategy on ESL Students' Reading Achievement," Arab World English Journal (AWEJ), Vol. 7 Number.1 March, $2016 \quad$ DOI: https://dx.doi.org/10.24093/awej/vol7no1.27, Pp.445-458

[13] S. Kagan, and M. Kagan, "Why Do We Need Cooperative Learning?” 2009.

[14] Kementerian Pendidikan dan Kebudayaan, Model silabus mata pelajaran sekolah menengah pertama/madrasah tsanawiyah (smp/mts) mata pelajaran bahasa inggris kementerian, 2017

[15.] F. H. Adams, Using jigsaw technique as an effective way of promoting co-operative learning among primary six pupil in fijai. International Journal Education and Practice, 2013;1(6), pp.64-74. 